\title{
HPLC, UV-vis and NMR spectroscopic and DFT characterization of purpurin isolated from Rubia tinctorum $\mathrm{L}$.
}

\author{
Zoran S. Marković ${ }^{1}$, Nedeljko T. Manojlović ${ }^{2}$, Svetlana R. Jeremić ${ }^{1}$, Miroslav Živić $^{3}$ \\ ${ }^{1}$ State University of Novi Pazar, Department of Chemical-Technological Sciences, Novi Pazar, Serbia \\ ${ }^{2}$ University of Kragujevac, Faculty of Medicinal Sciences, Department of Pharmacy, Kragujevac, Serbia \\ ${ }^{3}$ University of Belgrade, Faculty of Biology, Belgrade, Serbia
}

\begin{abstract}
Purpurin (1,2,4-trihidroxyanthraquinone), a naturally occuring anthraquinone pigment present in the root of Rubia tinctorum (Mull. Arg.) Zahlbr. was isolated from the plant, purified and characterized by HPLC chromatography, UV-vis and NMR spectroscopy. The geometries of the purpurin conformers were optimized using the B3LYP/6-311+G(d,p) level of theory. It was found that all conformations have similar energies and that the corresponding purpurin radicals are planar. In spite of their planarity, there is no significant electron delocalization over the $A$ and $C$ rings. The antioxidant properties of purpurin were investigated using the colorimetric assay as Trolox-equivalent antioxidant capacity, and theoretical BDE (Bond Dissociation Enthalpy). Both methods revealed that purpurin has strong antioxidant capacity.
\end{abstract}

Keywords: Rubia tinctorum, HPLC-UV, antioxidant activity, anthraquinone, DFT study.

SCIENTIFIC PAPER

UDC 547.673:58:543.42

Hem. Ind. 67 (1) 77-88 (2013)

doi: 10.2298/HEMIND120419058M

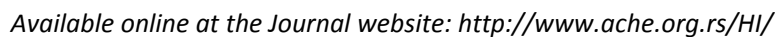

Anthraquinones are the largest and most important group of naturally accurring quinones. They are used as natural and synthetic color and are constituents of plants used for dyeing materials [1]. Many plants contain anthraquinones are used as pharmaceutical drugs [2,3]. Numerous antraquinones have a linear tricyclic ring framework, with various number of phenolic functional groups. A wide range of biological and pharmacological activities of anthraquinones, such as antimicrobial, antiviral, anti-inflammatory, anti-cancer, antioxidant, and antifungal [4-11] depend on their tricyclic scaffold, and on the nature and/or positions of substituents [12]. As anthraquinones have similar structure as flavonoids, a similar approach can be applied. Herbs containing anthraquinone derivatives are used as laxatives. The root of Rubia tinctorum (madder) is the source of natural anthraquinone dyes, including the most important alizarin and purpurin. Besides alizarin and purpurin, 35 other anthraquinone glycosides and aglycons have been reported as constituents of this plant [13]. The anthraquinones found in Rubia tinctorum differ in the nature of their substituents and in their substitution pattern.

Recent scientific studies have confirmed that purpurin, alizarin and their derivatives possess biological activity including antimicrobial and cytotoxic activities, and also have a strong inhibitory effect on the genotoxicity of several carcinogens [14-17]. Extract of Rubia

Correspondence: N. Manojlović, Department of Pharmacy, Medical Faculty, University of Kragujevac, 34000 Kragujevac, Serbia.

E-mail: ntm@kg.ac.rs

Paper received: 19 April, 2012

Paper accepted: 28 May, 2012 tinctorum has been used for treatment of kidney and bladder stones $[18,19]$. Several screening methods of anthraquinones in Rubia tinctorum L., based on reversed-phase high-performance liquid chromatography (RP-HPLC) have been described in literature $[12,20]$.

There are two basic and most applicable reaction pathways through which free radicals $\left(\mathrm{ArO}^{\circ}\right)$ are formed from antraquinones (ArOH). The first includes rapid hydrogen atom donation to a present radical (1), through which a new radical, more stable than the initial one, is formed (Hydrogen Atom Transfer-mechanism - HAT), leading to the direct $\mathrm{OH}$ bond breaking.

$\mathrm{ArOH}+\mathrm{HO}^{\circ} \rightarrow \mathrm{ArO}^{\circ}+\mathrm{HOH}$

The second reaction pathway is Proton-Coupled Electron Transfer (PCET) mechanism (2), by which the primary antioxidant transforms into radical cation, donating an electron to a free radical present in the system (e.g. lipid or some other radical). This mechanism leads to indirect $\mathrm{H}$-abstraction.

$\mathrm{ArOH}+\mathrm{HO}^{\bullet} \rightarrow \mathrm{ArOH}^{+\bullet}+\mathrm{OH}^{-} \rightarrow \mathrm{ArO}^{\bullet}+\mathrm{HOH}$

In the HAT mechanism the proton and electron are transferred together, whereas in the PCET mechanism the proton and electron are transferred between different sets of molecular orbitals [21-24]. The net result of both reactions is the same. The reactions occur in parallel by different rates. Many important biochemical processes obey the above mentioned mechanisms.

Both HAT and PCET mechanisms have been the subject of investigation. Which mechanism will be dominant in a given reaction depends on the phenolic $\mathrm{OH}$ 
bond strengths. The $\mathrm{OH}$ bond strength can be expressed as the $\mathrm{OH}$ bond dissociation enthalpy $(B D E)$. This molecular property can be used in the assessment of possible radical scavenging potential of the molecule. $B D E$ is calculated as the difference between the molecule (purpurin in this case) and its radical enthalpies. Density functional theory (DFT) often produces reliable results on the $B D E$ with relatively reasonable computational cost [25-36]. It is worth pointing out that the small $B D E$ value means that the $\mathrm{OH}$ bond is weak, and that the reaction will probably obey the fast HAT mechanism. On the other hand, in the PCET mechanism, the ionization potential of $\mathrm{ArOH}$ plays an important role, because the rate of formation of $\mathrm{ArOH}^{+\bullet}$ determines the rate of the overall reaction. Whichever mechanism is operative, removing a hydrogen atom from $\mathrm{ArOH}$ needs to be easier than that from $\mathrm{HOH}$. This means that both reactions (1) and (2) should be thermodynamically favorable, and that the formed radical species $\mathrm{ArO}^{\circ}$ needs to be relatively stable. In this way, the antioxidant molecule prevents or postpones toxic effects of radicals (such as the oxidative stress), slowly reacting with the substrate and faster with the present radicals. In these reactions, neither the antioxidant molecule nor the final product obtained from it have toxic or pro-oxidant effects [37].

The first part of this work is devoted to HPLC characterization of Rubia tinctorum L. specimens collected in central Serbia, isolation of major pigment, purpurin, and its characterization by UV-vis and NMR spectrescopy, and determination of its antioxidant capacity. In addition, a DFT study on the reactivity of the $\mathrm{OH}$ groups in purpurin and the structural and electronic features of the purpurin radicals were performed. The results for $B D E, H O M O$, and spin density of purpurin are presented. Structure-activity relationships are examined in the light of these results. Particular attention is devoted to the DFT interpretation of the reactivity of the $\mathrm{OH}$ groups in purpurin and the radicals formed after $\mathrm{H}$ removal from this molecule. Keto-enol tautomerism before $\mathrm{H}$-abstraction is also discussed to explain the role of the $\mathrm{OH}$ groups.

\section{EXPERIMENTAL}

\section{Chemical reagents}

All reagents used in the experiment were analytical grade in the highest purity available. Acetonitrile was of HPLC grade, and was purchased from Merck (Darmstadt, Germany). Deionized water used throughout the experiments was generated by a Milli-Q academic water purification system (Milford, MA, USA).

\section{Plant material}

Plant material was collected from Central Serbia (10 $\mathrm{km}$ south of the Aranđelovac town) during July, 2008.
The studied plant was identified by Prof. Dr. Vasiljević, Department of Biology, Faculty of Science, University of Niš, Serbia, as Rubia tinctorum (L.) (voucher specimen UNI-2403).

\section{Preparation of plant extract and isolation of purpurin}

The plant material was air dried at room temperature $\left(26^{\circ} \mathrm{C}\right)$ for one week, after which it was grinded to a uniform powder. After extraction with methanol the residue was hydrolysis with $2 \mathrm{~mol} / \mathrm{L} \mathrm{HCl}$, neutralized with solution $\mathrm{NaOH}$ and extracted with methanol. After evaporation of the solvent, the residue was partitioned between chloroform and water. The chloroform fraction was extracted with $1 \mathrm{~mol} / \mathrm{L} \mathrm{NaOH}$, which was then acidified with $\mathrm{HCl}$ and extracted with chloroform. This extract was chromatographed on Sephadex LH-20 (eluent chloroform-methanol 20:1, 10:1, 5:1 and 1:1) to yield purpurin which was identified according to spectral data [38]. Purpurin is a crystalline solid that forms red needles melting at $260^{\circ} \mathrm{C}$.

\section{High-performance liquid chromatography (HPLC) analysis}

High-performance liquid chromatography (HPLC) analysis was carried out on an Agilent 1200 Series HPLC instrument with $\mathrm{C} 18$ column (C18; $25 \mathrm{~cm} \times 4.6 \mathrm{~mm}, 10$ $\mathrm{m})$ and UV-vis spectrophotometric detector with two solvents, water and acetonitrile, in a linear gradient program (Table 1). The sample injection volume was 10 $\mu \mathrm{l}$. The flow rate of the mobile phase was kept constant at $1.0 \mathrm{~mL} \mathrm{~min}^{-1}$ and the chromatogram was recorded at $250 \mathrm{~nm}$ while the UV spectra were monitored over a range of 600 to $200 \mathrm{~nm}$. Purpurin was identified by comparison of its retention time and absorption spectrum to this of standard solution of purpurin.

Table 1. Gradient table for HPLC analysis

\begin{tabular}{lcc}
\hline Time, $\min$ & Water, $\%$ & Acetonitrile, \% \\
\hline 0 & 70 & 30 \\
5 & 75 & 25 \\
20 & 40 & 60 \\
30 & 30 & 70 \\
40 & 75 & 25 \\
45 & 70 & 30 \\
\hline
\end{tabular}

\section{NMR Spectra}

The ${ }^{1} \mathrm{H}$ - and ${ }^{13} \mathrm{C}$-NMR spectra of purpurin were recorded at room temperature on a Bruker NMR spectrometer (500 MHz for ${ }^{1} \mathrm{H}$ - and $125 \mathrm{MHz}$ for ${ }^{13} \mathrm{C}-\mathrm{NMR}$ ). TMS was used as internal standard. The samples were prepared by the dissolution of purpurin in DMSO (signal for ${ }^{1} \mathrm{H}$ - at $2.5 \mathrm{ppm}$ and at $39.5 \mathrm{ppm}$ for ${ }^{13} \mathrm{C}-\mathrm{NMR}$ ). 


\section{Antioxidant activity}

The 2,2'-azinobis-(3-ethylbenzothiazoline-6-sulphonic acid) (ABTS) and 6-hydroxy-2,5,7,8-tetramethylchroman-2-carboxylic acid (Trolox) were obtained from Fluka (Switzerland). The total antioxidant activity of purpurin was determined by the colorimetric assay as Trolox-equivalent antioxidant capacity (TEAC). The stable ABTS radical monocation $\left(\mathrm{ABTS}^{+\bullet}\right)$ was generated by the incubation of $7 \mathrm{mM}$ ABTS with $2.5 \mathrm{mM}$ potassium persulfate in the dark at room temperature for 16 $\mathrm{h}$ before use. The ABTS ${ }^{+}$solution was diluted immediately prior to assay to an absorbance of $0.70 \pm 0.02$ at $734 \mathrm{~nm} .500 \mu \mathrm{L}$ of diluted $\mathrm{ABTS}^{+\bullet}$ solution was placed in the quartz cuvette to record the initial absorbance. Then, various concentrations of purpurin or Trolox were added to each cuvette, mixed by inversion, and the absorbance was read exactly at $60 \mathrm{~s}$ after addition. Parallel blanks were performed in each assay with the appropriate solvent alone. The percentage inhibition compared to initial absorbance after $60 \mathrm{~s}$ was plotted as a function of sample or Trolox concentration. TEAC value was expressed as the ratio of sample and Trolox slope $\left(a_{\text {sample }} / a_{\text {Trolox }}\right)$. Each assay was carried out in triplicate.

\section{Computational method}

All calculations were performed in vacuum, using Gaussian09 software package [39], at the B3LYP/6$-311+G(d, p)$ level of theory [40]. Six different in-plane conformations of purpurin were found and investtigated. The differences between conformations are in $\mathrm{OH}$ groups orientation at $\mathrm{C} 1, \mathrm{C} 2$, and $\mathrm{C} 4$ atoms. Obtained geometries were verified to be minima on the potential energy surface by a normal mode analysis no imaginary frequencies were found. Transitions to the lowest excited singlet electronic states of purpurin were computed by using the TD-B3LYP procedure [40$-42]$. The influence of methyl alcohol as solvent upon the electronic transitions was approximated by the polarized continuum model PCM $[43,44]$. UV-vis spec- tral analysis was performed using ChemCraft 1.5 [46], and Gaussum [45]. The calculation of NMR spectrum of purpurin was performed using the GIAO (Gauge-Including Atomic Orbitals) method $[47,48]$, implemented in the Gaussian package. In order to express the chemical shifts in ppm, the geometry of the tetramethylsilane (TMS) molecule was optimized, and then its NMR spectrum was calculated by using the same method and basis set as for the calculation of purpurin molecule.

The obtained zero point energies were used to correct all energetic terms using the recommended scaling factor of 0.9887 [49]. Natural bond orbital (NBO) analysis [50] was performed for all structures. Bond dissociation enthalpy $(B D E)$ for purpurin (Table 2) was calculated using the following equation:

$B D E=H_{\mathrm{POH}}-H_{\mathrm{PO}} \cdot-H_{\mathrm{H}^{\circ}}$

where $H_{\mathrm{POH}}, H_{\mathrm{PO}}$, and $H_{\mathrm{H}^{*}}$ present the enthalpy of purpurin, purpurin radical, and hydrogen atom, respectively. The ionization potential (IP) was obtained as the energy difference between the $\mathrm{POH}$ and $\mathrm{POH}^{+\bullet}$ species.

\section{RESULTS AND DISCUSSIONS}

The HPLC chromatogram of the crude extract of Rubia tinctorum is shown in Figure 1 . The $t_{\mathrm{R}}$ values for purpurin is $25.24 \mathrm{~min}$. Beside purpurin, very important anthraquinone alizarin was also identified $\left(t_{R}=23.64\right.$ $\mathrm{min})$. The identification of these compounds were performed by comparison of their $t_{R}$ values with the standard substances. The UV-vis absorbance spectral results also correspond to the literature data [51]. Bearing in mind the importance of the pigment purpurin, this anthraquinone was isolated from the extract by column chromatography on silica gel. Purpurin contains three hydroxyl groups located in the same ring. These groups can play an important role in the expression of antioxidant activity of purpurin.

Table 2. Calculated energies of the purpurin rotamers (1 to 6), purpurin radicals (1-OH, 2-OH, and 4-OH, and keto forms of purpurin

\begin{tabular}{lcccc}
\hline Compound & Total energy, a.u. & Enthalpy, a.u. & Free energy, a.u. & $B D E, \mathrm{~kJ} / \mathrm{mol}$ \\
\hline $\mathbf{1}$ & -914.5376 & -914.5269 & -914.5802 & - \\
$\mathbf{2}$ & -914.5303 & -914.5185 & -914.5721 & - \\
$\mathbf{3}$ & -914.5160 & -914.5037 & -914.5587 & - \\
$\mathbf{4}$ & -914.5169 & -914.5047 & -914.5593 & - \\
$\mathbf{5}$ & -914.5072 & -914.4947 & -914.5501 & - \\
$\mathbf{6}$ & -914.4937 & -914.4806 & -914.5389 & - \\
1-OH & -913.9010 & -914.8891 & -913.9441 & 362.15 \\
2-OH & -913.8997 & -913.8879 & -913.9421 & 365.28 \\
4-OH & -913.8862 & -913.8741 & -913.9294 & 401.58 \\
Keto C-2 & -914.4638 & -914.4514 & -914.5072 & 163.80 \\
Keto C-11 & -914.4940 & -914.4822 & -914.5363 & 244.68 \\
\hline
\end{tabular}




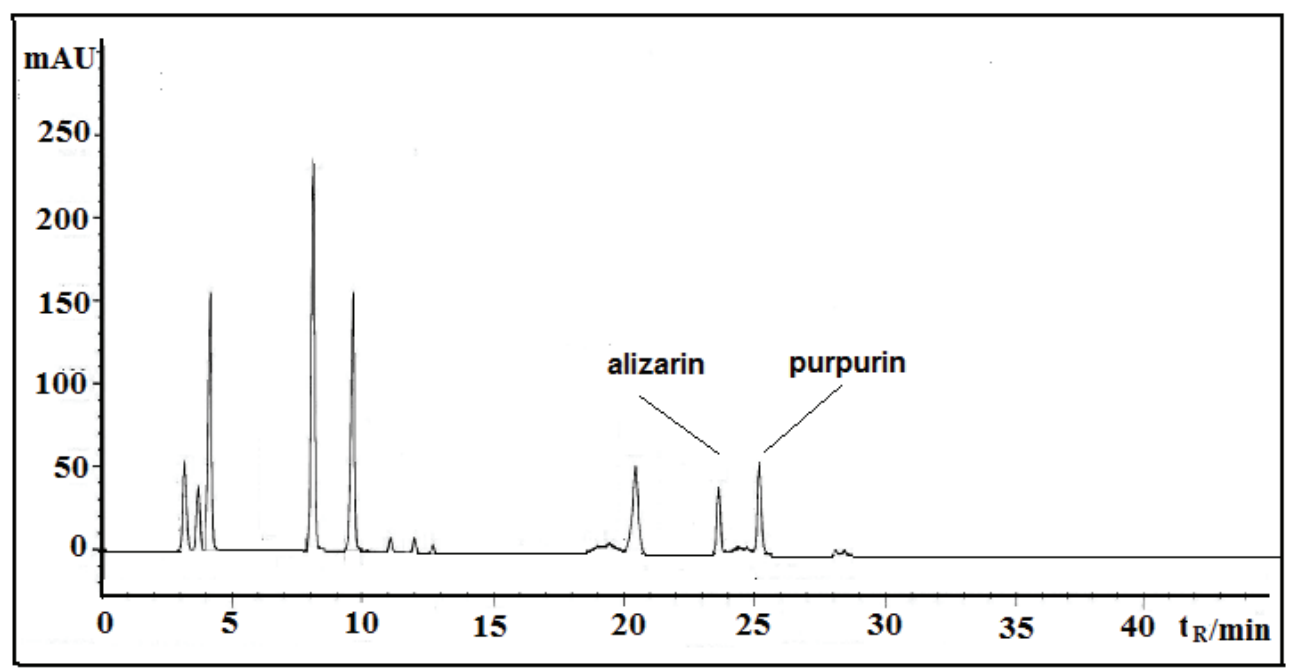

Figure 1. HPLC Chromatogram of the Rubia tinctorum specimen.

To find the most stable conformation of purpurin, which will be used for further investigations, the conformational space of purpurin was explored as a function of the torsion angles $\tau 1$ (C2-C1-O1-H), $\tau 2$ (C3-C2$-\mathrm{O} 2-\mathrm{H})$ and $\tau 3$ (C3-C4-O4-H). In this way, the preferred relative positions among $\mathrm{OH}$ groups in relation to benzene ring were determined. The minimization procedure yielded a planar conformation $\left(\tau 1=\tau 2=\tau 3=180^{\circ}\right)$ as the most stable structure ( $\mathbf{1}$ in Figure 2 ). By removing constraint for the torsion angles, the conformational absolute minimum was found at $(\tau 1=\tau 2=\tau 3=$ $=180^{\circ}$. Five local minima were also found, i.e., conformations 2-6, which are less stable than 1 by 22.1, $60.9,58.3,84.5$, and $121.5 \mathrm{~kJ} / \mathrm{mol}$, respectively (Table 2 and Figure 2). Figure 2 shows that there is no deviation from planarity in any conformation of purpurin.
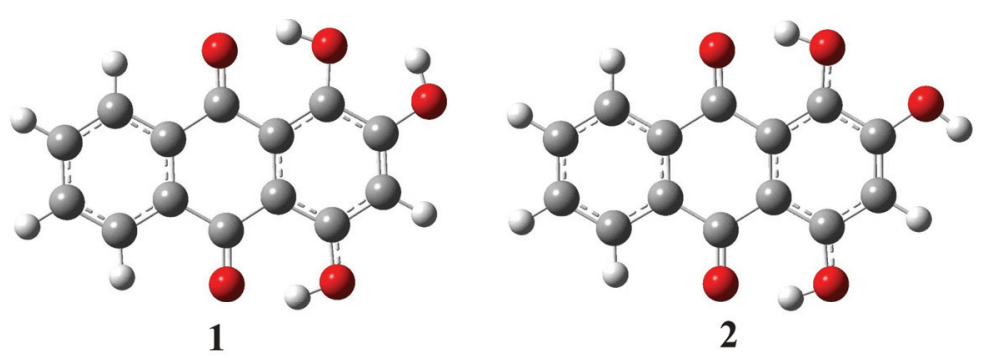

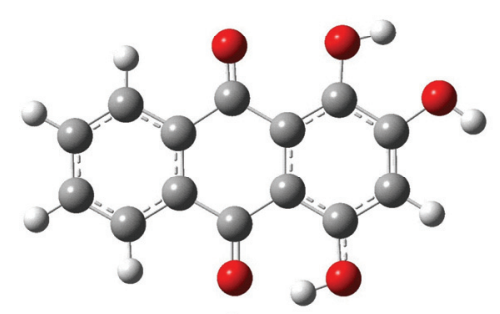

3

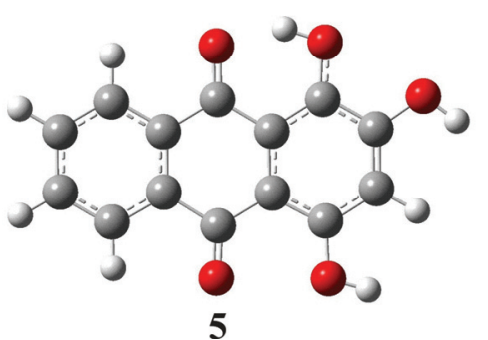

5
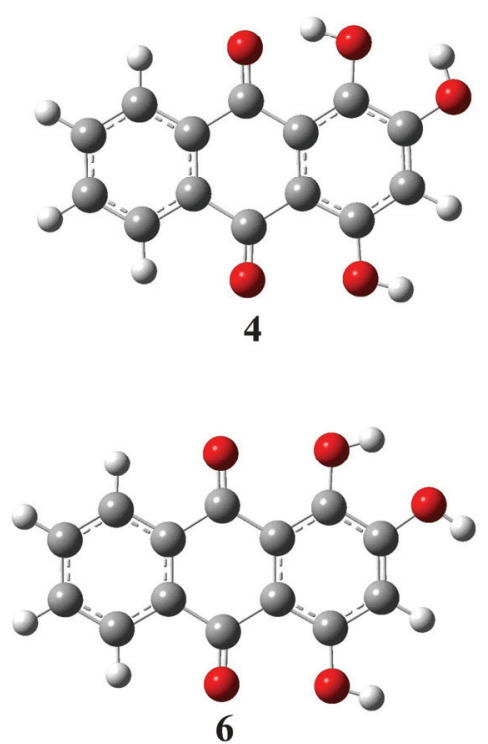

Figure 2. The optimized geometries of the six conformations for purpurin. 
Bond lengths of the absolute minimum 1 calculated in vacuum and methanol as solvent are presented in Table 3. Table 3 shows that there are no significant differences between the geometries optimized in vacuum and methanol. In addition, it is evident that the majority of bonds in rings are longer than double bond, and shorter than single bond. The double bonds around the carbonyl groups in the ring $\mathrm{C}$ indicate a cross-conjugated system in which the delocalization is allowed only between $A$ and $C$, or $B$ and $C$, but not between $A$ and $B$ rings. The results of $N B O$ analysis of 1 reveal two strong double bonds in C9-O and C10-O carbonyl groups, which form hydrogen bonds with the hydrogens of the adjacent hydroxyl groups. These hydrogen bonds have a significant stabilizing effect, as in emodin [52] and lichexanthone [53]. Structure 6, which lacks these hydrogen bonds, is the most unstable conformation of purpurin (Table 2).

To verify the geometry obtained by the DFT method, detailed analysis of the experimental and theoretical UV-vis and NMR spectra was performed. Both experimental and theoretical UV-vis spectra are presented in Figure 3, whereas calculated electronic transitions are given in Table 4 . There is generally a very satisfactory agreement between the observed and predicted wave numbers and intensities.

The maximum for band $A$, whose calculated value is $467 \mathrm{~nm}$, corresponds to the experimental value of 482

Table 3. Bond lengths of purpurin (1) and its radicals $(1-\mathrm{OH}, 2-\mathrm{OH}$ and $3-\mathrm{OH})$ calculated using $\mathrm{B} 3 \mathrm{LYP} / 6-311+G(d, p)$ level of theory

\begin{tabular}{|c|c|c|c|c|c|}
\hline \multirow{2}{*}{ Species bond } & \multicolumn{5}{|c|}{ Length, nm } \\
\hline & 1 & 1 (methanol) & $1-\mathrm{OH}$ & $2-\mathrm{OH}$ & $4-\mathrm{OH}$ \\
\hline $\mathrm{C} 1-\mathrm{C} 2$ & 0.1427 & 0.1424 & 0.1489 & 0.1499 & 0.1435 \\
\hline $\mathrm{C} 2-\mathrm{C} 3$ & 0.1377 & 0.1377 & 0.1366 & 0.1437 & 0.1359 \\
\hline C3-C4 & 0.1408 & 0.1406 & 0.1407 & 0.1376 & 0.1459 \\
\hline $\mathrm{C} 4-\mathrm{C} 12$ & 0.1411 & 0.1410 & 0.1442 & 0.1445 & 0.1478 \\
\hline C10-C12 & 0.1451 & 0.1450 & 0.1469 & 0.1464 & 0.1483 \\
\hline $\mathrm{C} 10-\mathrm{C} 13$ & 0.1488 & 0.1484 & 0.1473 & 0.1482 & 0.1502 \\
\hline C5-C13 & 0.1398 & 0.1398 & 0.1401 & 0.1399 & 0.1397 \\
\hline C5-C6 & 0.1390 & 0.1391 & 0.1388 & 0.1390 & 0.1390 \\
\hline C6-C7 & 0.1398 & 0.1397 & 0.1399 & 0.1398 & 0.1399 \\
\hline $\mathrm{C} 7-\mathrm{C} 8$ & 0.1389 & 0.1390 & 0.1390 & 0.1389 & 0.1388 \\
\hline C8-C14 & 0.1399 & 0.1399 & 0.1397 & 0.1399 & 0.1401 \\
\hline C13-C14 & 0.1408 & 0.1410 & 0.1404 & 0.1407 & 0.1405 \\
\hline C9-C14 & 0.1480 & 0.1478 & 0.1497 & 0.1477 & 0.1469 \\
\hline C9-C11 & 0.1464 & 0.1464 & 0.1488 & 0.1465 & 0.1475 \\
\hline $\mathrm{C} 11-\mathrm{C} 12$ & 0.1428 & 0.1428 & 0.1405 & 0.1422 & 0.1406 \\
\hline C1-C11 & 0.1392 & 0.1392 & 0.1453 & 0.1406 & 0.1415 \\
\hline C1-O1 & 0.1346 & 0.1344 & 0.1239 & 0.1305 & 0.1326 \\
\hline $\mathrm{C} 2-\mathrm{O} 2$ & 0.1348 & 0.1348 & 0.1323 & 0.1232 & 0.1351 \\
\hline C4-O3 & 0.1336 & 0.1341 & 0.1318 & 0.1338 & 0.1237 \\
\hline C9-O4 & 0.1243 & 0.1245 & 0.1219 & 0.1243 & 0.1245 \\
\hline C10-O5 & 0.1245 & 0.1249 & 0.1246 & 0.1242 & 0.1219 \\
\hline $\mathrm{D}_{\mathrm{H}}(\mathrm{O} 4 \cdots \mathrm{H}-\mathrm{O} 1)$ & 0.1675 & 0.1674 & - & 0.1615 & 0.1575 \\
\hline $\mathrm{D}_{\mathrm{H}}(\mathrm{O} 1 \cdots \mathrm{H}-\mathrm{O} 2)$ & 0.2116 & 0.2138 & 0.194563 & - & 0.2124 \\
\hline $\mathrm{D}_{\mathrm{H}}(\mathrm{O} 5 \cdots \mathrm{H}-\mathrm{O} 3)$ & 0.1679 & 0.1662 & 0.157677 & 0.1683 & - \\
\hline
\end{tabular}



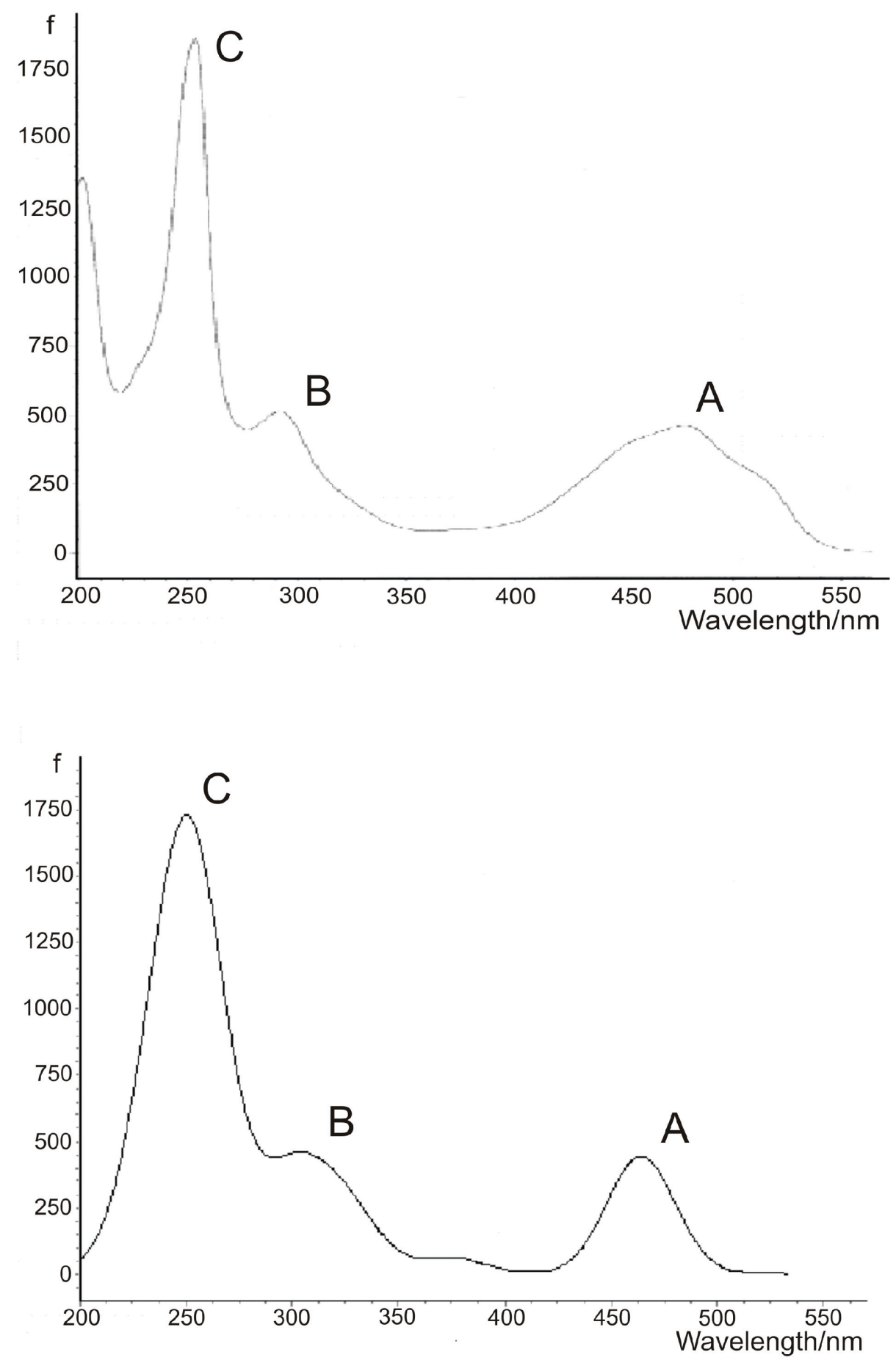

Figure 3. Experimental (top) and calculated (bottom) UV spectra for purpurin.

$\mathrm{nm}$. This is essentially a HOMO-LUMO transition, involving excitation from $\pi$ to $\pi^{*}$. The shapes of the orbitals are shown in Figure 4. They indicate that the transition is associated with significant charge-transfer form the ring $B$ to the ring $A$, similar to the situation characterizing the color bands in related compounds, such as chrysazin and anthralin, and the first strong UV-Vis band of the parent anthraquinone chromophore [54].
Similar charge transfer from the ring $A$ to the ring $B$ is observed for peak $B$, whose theoretical maximum is predicted at $305 \mathrm{~nm}$. This band is in good agreement with the experimental polarization value of $291 \mathrm{~nm}$. This transition involves excitation from HOMO-4 to LUMO. The experimental value for peak $C$ at $252 \mathrm{~nm}$ is in excellent agreement with the calculated electronic transition of $254 \mathrm{~nm}$. This peak mainly represents excitation from HOMO-1 to LUMO+1. 
Table 4. Experimental and calculated electronic transitions for purpurin; $\lambda$-wave numbers in $n m, f$-oscillator strength

\begin{tabular}{|c|c|c|c|c|}
\hline \multirow{2}{*}{ Case } & \multirow{2}{*}{$\frac{\text { Experimental }}{\lambda}$} & \multicolumn{3}{|c|}{ TD- B3LYP/6-311+G(d,p) } \\
\hline & & $\Lambda$ & $f$ & Leading configurations \\
\hline$A$ & 482 & 466.9 & 0.2028 & $\mathrm{H} \rightarrow \mathrm{L}(98 \%)$ \\
\hline B & 291 & 305.3 & 0.1675 & $\mathrm{H}-4 \rightarrow \mathrm{L}(81 \%)$ \\
\hline C & 252 & 254.2 & 0.6015 & $\begin{array}{c}H-1 \rightarrow L+1(69 \%) \\
H \rightarrow L+2(17 \%)\end{array}$ \\
\hline
\end{tabular}

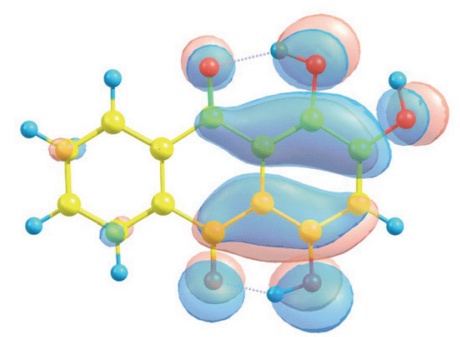

HOMO

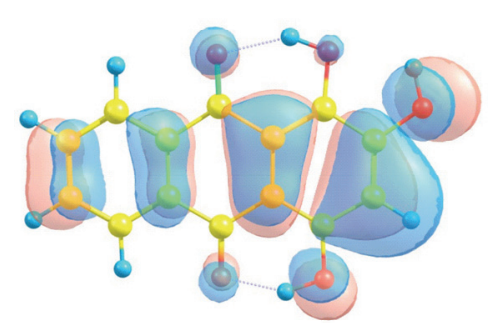

HOMO-1

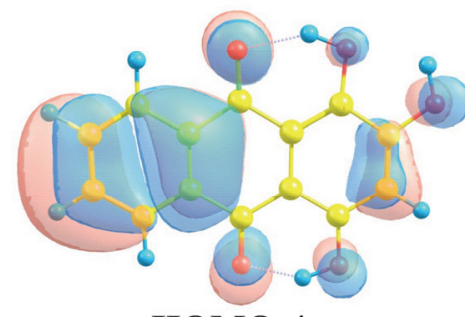

HOMO-4

Figure 4. Selected molecular orbitals for purpurin.

The experimental and calculated ${ }^{1} \mathrm{H}$ - and ${ }^{13} \mathrm{C}-\mathrm{NMR}$ spectra of purpurin are presented in Table 5.

Obviously, there is a very good agreement between the experimental and theoretical values for the chemical shifts of the proton spectrum. Scaled theoretical values (scaling factor 0.953 ) for ${ }^{13} \mathrm{C}$ chemical shifts are also in accord with the experimental data. The agreement between the experimental and theoretical results indicates that the structure of purpurin used for the UV-vis and NMR measurements corresponds to that of 1 (Figure 2).

It is well known that some anthraquinones are very good antioxidants. The structure of purpurin indicates a possibility of conjugation and antioxidant properties. This assumption is based on the suggestion of van
Acker et al. [55] and Rice-Evans et al. [56], who supposed that the antioxidant properties of flavonoids could be derived just from their good delocalization possibilities. The same consideration can be applied to anthraquinones. Bearing this in mind, purpurin was screened for its antioxidant potential using the relative ability to scavenge the $\mathrm{ABTS}^{+\bullet}$ radical cation generated in the aqueous phase, expressed as the Trolox equivalent antioxidant capacity (TEAC). Purpurin was found

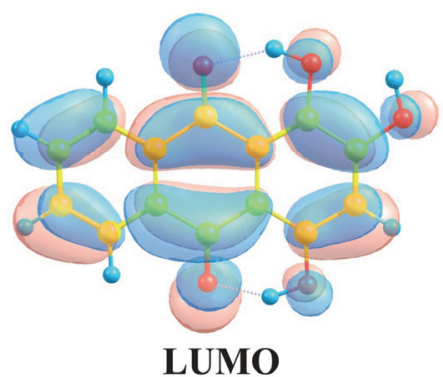

LUMO

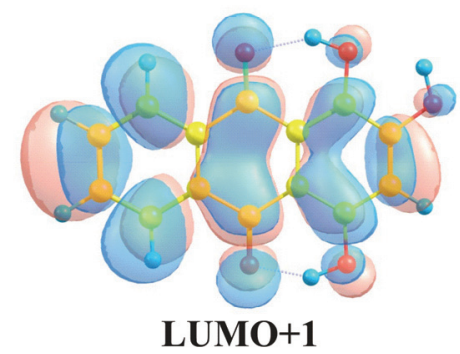

LUMO+1

Table 5. Experimental and theoretical chemical shifts (in ppm) for purpurin molecule

\begin{tabular}{lcc|lcc}
\hline Atom & Exp. & Calcd. & Atom & Exp. & Calcd. \\
\hline C1 & 157.1 & 152.8 & C12 & 109.7 & 111.3 \\
C2 & 149.3 & 152.3 & C13 & 133.3 & 141.6 \\
C3 & 126.6 & 116.1 & C14 & 134.5 & 138.9 \\
C4 & 160.3 & 169.2 & H1 & 13.2 & 13.5 \\
C5 & 126.2 & 133.3 & H2 & 11.6 & 11.3 \\
C6 & 134.1 & 140.8 & H3 & 6.5 & 6.4 \\
C7 & 134.9 & 139.1 & H4 & 12.9 & 13.4 \\
C8 & 126.5 & 133.1 & H5 & 8.0 & 8.6 \\
C9 & 183.3 & 194.5 & H6 & 7.8 & 7.5 \\
C10 & 186.6 & 190.0 & H8 & 7.8 & 7.9 \\
C11 & 112.4 & 118.4 & H8 & 8.1 & 8.7 \\
\hline
\end{tabular}


to have the TEAC value of $1.950 \pm 0.008 \mathrm{mM}$. This result is in agreement with that reported [57], and indicates that purpurin has a good antioxidant activity.

There is no detailed description of the radical cation of purpurin in literature. The radical cation formed by removing an electron from 1, Figure 2, is planar, and hydrogen bonds are retained as in the parent molecule, contributing to further stabilization. The obtained value for the ionization potential $(744.2 \mathrm{~kJ} / \mathrm{mol})$ of 1 is higher than the corresponding values for flavonoids [25], but is lower than the corresponding values for emodin and lichexanthone [52,53]. On the basis of the ionization potential value, stronger antioxidant activity of purpurin than that for emodin and lichexanthone can be expected.

It is well known that there is good correlation between antioxidant activity and $B D E$ values [25,52]. For this reason, the values of $B D E$ for the $\mathrm{OH}$ groups of purpurin were determined. The obtained results (Table 2) show that $1-\mathrm{OH}$ and $2-\mathrm{OH}$ groups are responsible for the antioxidant activity of purpurin. The $B D E$ value for homolytic cleavage of the $1-\mathrm{OH}$ bond is higher than those for dissociation of the $\mathrm{OH}$ groups in fisetin [58], and particularly in quercetin $[25,26]$. On the other hand, the obtained value is lower than the corresponding value for emodin [52].

In the text below, some properties of the radicals, formed by homolytic cleavage of the $\mathrm{OH}$ groups of purpurin will be discussed. Geometry optimization of the radicals was performed by starting from the optimized structure of the parent molecule 1 , and removing a hydrogen atom from the $\mathrm{OH}$ groups at positions 1,2 and 4 . In the further discussion, the radical formed by $\mathrm{H}$-removal from the $x-\mathrm{OH}$ group of purpurin is called the $x-\mathrm{OH}$ radical $(x=1,2$, or 4 ), for example $2-\mathrm{OH}$ radical. Since the $B D E$ value for $4-\mathrm{OH}$ radical is significantly higher than that of $1-\mathrm{OH}$ radical by almost 40 $\mathrm{kJ} / \mathrm{mol}$, only $1-\mathrm{OH}$, and $2-\mathrm{OH}$ radicals will be further considered.

Inspection of the geometries of the obtained radicals shows that they retain planarity, like the parent molecule. Inspection of Table 3 allows further comment on the electronic structure of both radicals. In both radicals, complete delocalization involves only ring $A$, while ring $B$ is characterized by three double bonds in 1-OH radical (C1-O, C2-C3, and $\mathrm{C} 11-\mathrm{C} 12)$, and by two double bonds in 2-OH radical (C2-O and $\mathrm{C} 3-\mathrm{C} 4$ ). On the basis of these structural features of the radicals, it is clear that delocalization between rings $C$ and $B$ is restricted. A consequence of the restricted delocalization is the decreased stability of both radicals, implying that their $B D E$ values are slightly higher in comparison to those obtained for the majority of the flavones $[25,26,57]$.
To understand the relationship between the electron delocalization and the reactivity of a radical, the electron distribution in the singly occupied molecular orbital (SOMO) needs to be examined. The SOMO of the $1-\mathrm{OH}$ radical (Figure 5 ) is mainly delocalized over carbonyl groups. As SOMO is the $\alpha$-highest occupied molecular orbital, it does not describe the global electronic behavior of the radical, and its shape is not a reliable indicator for the reactivity of the purpurin radical.
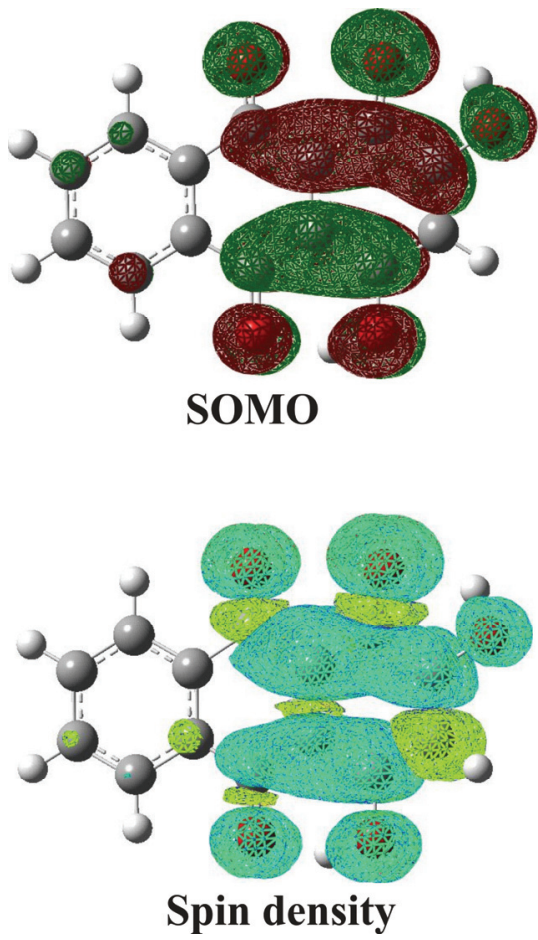

Figure 5. SOMO and spin density of the 1-OH radical.

Spin density is often considered to be a more realistic parameter, and provides a more reliable representation of the reactivity [54]. The importance of spin density for the description of flavonoids has been pointed out in the papers of Leopoldini et al. [25,26], and Marković et al. $[36,52,53]$. The lower the $B D E$ value, the more delocalized spin density in the radical, and easier radical formation are. As this consideration can be applied to antraquinones, the spin density in the purpurin radical was analyzed. The spin density distribution in the 1-OH radical indicates the oxygen atom bonded to $\mathrm{C} 1$ as the most probable radical center, followed by the adjacent carbons C2 and C11, and nonadjacent carbons C4 and C12 (Figure 5). Weak delocalization of the spin density exists over the ring $\mathrm{C}$.

The $\mathrm{OH}$ groups of purpurin can also undergo ketoenol tautomerism. Hydrogen atom from $1-\mathrm{OH}$ position can migrate to positions 2 or 11 , thus yielding two tautomers (Scheme 1). The BDE values for the formation of the $1-\mathrm{OH}$ radical by $\mathrm{H}$-abstraction from the $\mathrm{C} 2$ and 


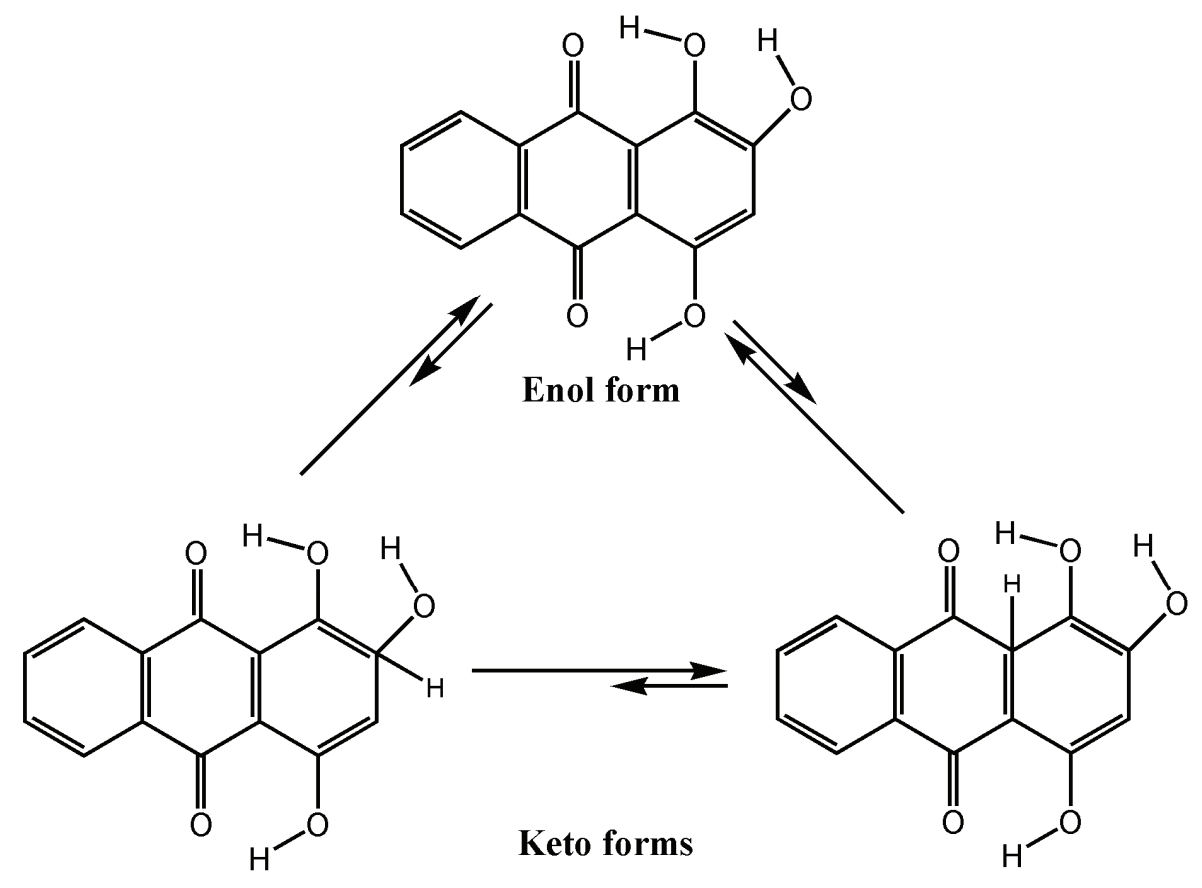

Scheme 1. Keto-enol tautomerism in purpurin.

C11 of the keto forms of 1 were calculated (Table 2), and the values of 163.80 and $244.68 \mathrm{~kJ} / \mathrm{mol}$ were obtained. These low $B D E$ values indicate the relatively high capacity of $\mathrm{H}$-removal from the $\mathrm{C} 11$, and especially from the C2 site in the keto forms. However, it should be noted that the keto forms of purpurin are less stable than the enols form, the latter being stabilized by $\pi$ conjugation in the B-ring. The differences in stability between 1, and C2 and C11 keto forms amount to 198.35 and $117.47 \mathrm{~kJ} / \mathrm{mol}$ in favor of purpurin. For instance, in the case of emodin and quercetin this difference in stability is only 61.5 and $83.8 \mathrm{~kJ} / \mathrm{mol}$ [52], whereas for lichexanthone it amounts $271.9 \mathrm{~kJ} / \mathrm{mol}$ [53]. These differences in stability between enol and keto forms indicate that the contribution of keto forms can be considered negligible for purpurin as a free molecule. On the other hand, it can be presumed that, in some enzymatic processes, stability difference between two forms is reduced, so that keto forms become relevant, and then $\mathrm{H}$-abstraction from the $\mathrm{C} 2$ or $\mathrm{C} 11$ positions can take place easily, thereby contributing to the antioxidant properties.

\section{CONCLUSIONS}

The HPLC characterization of the extract of Rubia tinctorum specimens collected in central Serbia was perfomed. The very important anthraquinone, purpurin, was isolated and identified using HPLC, UV-vis and NMR spectral methods. The purpurin structure was determined by B3LYP/6-311+G (d,p) method. Comparison of the calculated UV-vis and ${ }^{1} \mathrm{H}$ - and ${ }^{13} \mathrm{C}$-NMR spectra with the experimental data confirmed that structure 1, Figure 2, is likely structure of purpurin. Biological activity of anthraquinones is associated mainly with their tricyclic scaffold, but it may vary depending on the nature and/or position of substituents. On the basis of the obtained results, it is clear that purpurin, as well as its radicals, appears to be a planar tricyclic species. In spite of the planarity of the radical structure, there is no electronic delocalization between adjacent rings. It is supposed that this is one of the main reasons for higher values of $B D E$ in comparison to those for flavones. In addition, the increased $B D E$ values can be attributed to the cleavage of the strong hydrogen bonds, involved in the process of $\mathrm{H}$-removal. Theoretical results are in accord with the experimental TEAC value. It was found that enol form is the most stable tautomer of the free molecule. Keto forms, which possess some lower $B D E$ values for $\mathrm{H}$-abstraction on the $\mathrm{C} 2$ or $\mathrm{C} 11$ atoms, might play a significant role in real systems, depending on the molecular environment of purpurin and on oxidative system acting on the molecule.

\section{Acknowledgements}

The authors acknowledge financial support by the Ministry of Education, Science and Technological Development of the Republic of Serbia (Grants No. 172015 and 174028).

\section{REFERENCES}

[1] R.A. Muzychkina, Natural Anthraquinones, Biological and Physicochemical Properties, House Phasis, Moscow, 1998. 
[2] B. Li, D. M. Zhang, Y. M. Luo, X.G. Chen, Three new and antitumor anthraquinone glycosides from Lasianthus acuminatissimus MERR, Chem. Pharm. Bull. 54 (2006) 297-300.

[3] Y. Duan, J. Yu, S. Liu, M. Ji, Synthesis of anthraquinoneibuprofen prodrugs with hydroxyapatite affinity and anti-inflammatory activity characteristics, Med. Chem. 5 (2009) 577-582.

[4] Y. Akao, Y. Nakagawa, M. linuma, Y. Nozawa, Anti-cancer effects of xanthones from pericarps of mangosteen, Int. J. Mol. Sci. 9 (2008) 355-370.

[5] L.G. Chen, L.L. Yang, C.C. Wang, Anti-inflammatory activity of mangostins from Garcinia mangostana, Food Chem. Toxicol. 46 (2008) 688-693.

[6] S. Suksamrarn, O. Komutiban, P. Ratananukul, N. Chimnoi, N. Lartpornmatulee, A. Suksamrarn, Cytotoxic prenylated xanthones from the young fruit of Garcinia mangostana, Chem. Pharm. Bull. 54 (2006) 301-305.

[7] J. Pedraza-Chaverri, N. Cárdenas-Rodríguez, M. OrozcoIbarra, J.M. Pérez-Rojas, Medicinal properties of mangosteen (Garcinia mangostana), Food Chem. Toxicol. 46 (2008) 3227-3239.

[8] G. Gopalakrishnan, B. Banumathi, G.J. Suresh, evaluation of the antifungal activity of natural xanthones from Garcinia mangostana and their synthetic derivatives, Nat. Prod. 60 (1997) 519-524.

[9] T.N. Manojlovic, S. Solujic, S. Sukdolak, Antimicrobial activity of an extract and anthraquinones from Caloplaca schaereri, Lichenologist 34 (2002) 83-85.

[10] J.C. Cyoug, T. Matsumoto, K. Arakawa, H. Kiyohara, H. Yamoda, Y. Otsuka, Anti-Bacteroides fragilis substance from Rhubarb, J. Ethnopharmacol. 19 (1987) 279-283.

[11] G.C. Yen, P.D. Duh, D.Y. Chuang, Antioxidant activity of anthraquinones and anthrone, Food Chem. 70 (2000) 437-441.

[12] M.M.M. Pinto, M.E. Souza, M.S.J. Nascimento, Xanthone derivatives: New insights in biological activities, Curr. Medic. Chem. 12 (2005) 2517-2538.

[13] G.C.H. Derksen, H.A.G. Niederländer, T.A. van Beek, Analysis of anthraquinones in Rubia tinctorum L. by liquid chromatography coupled with diode-array UV and mass spectrometric detection, J. Chromatogr., A 978 (2002) 119-127.

[14] J.N. Hao, M.P. Huang, H. Lee, Structure-activity relationships of anthraquinones as inhibitors of 7-ethoxycoumarin $O$-deethylase and mutagenicity of 2-amino-3methylimidazo [4,5-f] quinoline, Mutat. Res. 328 (1995) 183-191.

[15] T.H. Marczylo, T. Hayatsu, S. Arimoto-Kobayashi, M. Tada, K. Fujita, T. Kamataki, K. Nakayama, H. Hayatsu, Protection against the bacterial mutagenicity of heterocyclic amines by purpurin, a natural anthraquinone pigment, Mutat. Res. 444 (1999) 451-461.

[16] T.H. Marczylo, S. Arimoto-Kobayashi, H. Hayatsu, Protection against Trp-P-2 mutagenicity by purpurin: mechanism of in vitro antimutagenesis, Mutagenesis 15 (2000) 223-228.
[17] N.T. Manojlović, S. Solujić, S. Sukdolak, M. Milošev, Antifungal activity of Rubia tinctorum, Rhamnus frangula and Caloplaca cerina, Fitoterapia 76 (2005) 244-246.

[18] J. Westendorf, W. Pfau, A. Schulte, Carcinogenicity and DNA adduct formation observed in $\mathrm{ACl}$ rats after longterm treatment with madder root, Rubia tinctorum L., Carcinogenesis 19 (1998) 2163-2168.

[19] B. Blömeke, B. Poginsky, C. Schmutte, H. Marquardt, J. Westendorf, Formation of genotoxic metabolites from anthraquinone glycosides, present in Rubia tinctorum L, Mutat. Res. 265 (1992) 263-272.

[20] P. Bányai, I.N. Kuzovkina, L. Kursinszki, É. Szőke, HPLC Analysis of Alizarin and Purpurin Produced by Rubia tinctorum L., Hairy Root Cultures 63 (2006) 111-114.

[21] M.J. Mayer, Proton-coupled electron transfer: A Reaction Chemist's View, Annu. Rev. Phys. Chem. 55 (2004) 363-390.

[22] G.A. DiLabio, R.E. Johnson, Lone pair- $\pi$ and $\pi-\pi$ interactions play an important role in proton-coupled electron transfer reactions, J. Am. Chem. Soc. 129 (2007) 6199-6203.

[23] G.A. DiLabio, K.U. Ingold, A theoretical study of the iminoxyl/oxime self-exchange reaction. A five-center, cyclic proton-coupled electron transfer, J. Am. Chem. Soc. 127 (2005) 6693-6699.

[24] M. Sjödin, S. Styring, B. Åkermark, L. Sun, L. Hammarström, Proton-coupled electron transfer from tyrosine in a tyrosine-ruthenium-tris-bipyridine complex: Comparison with tyrosinez oxidation in photosystem II, J. Am. Chem. Soc. 122 (2000) 3932-3936.

[25] M. Leopoldini, I.P. Pitarch, N. Russo, M. Toscano, Structure, conformation, and electronic properties of apigenin, luteolin, and taxifolin antioxidants. A First principle theoretical study, J. Phys. Chem., A 108 (2004) 92-96.

[26] M. Leopoldini, T. Marino, N. Russo, M. Toscano, Density functional computations of the energetic and spectroscopic parameters of quercetin and its radicals in the gas phase and in solvent, Theor. Chem. Acc. 111 (2004) 210-216.

[27] M. Lucarini, F. G. Pedulli, M. Guerra, A critical evaluation of the factors determining the effect of intramolecular hydrogen bonding on the $\mathrm{O}-\mathrm{H}$ bond dissociation enthalpy of catechol and of flavonoid antioxidants, ChemEur. J. 10 (2004) 933-939.

[28] K. Lemaska, H. Szymusiak, B. Tyrakowska, R. Zieliski, A.E.M.F. Soffers, I.M.C.M. Rietjens, The influence of $\mathrm{pH}$ on antioxidant properties and the mechanism of antioxidant action of hydroxyflavones, Free Radical Bio. Med. 31 (2001) 869-881.

[29] P. Trouillas, C. Fagnère, R. Lazzaroni, A.C. Calliste, A. Marfak, L.J. Duroux, A theoretical study of the conformational behavior and electronic structure of taxifolin correlated with the free radical-scavenging activity, Food Chem. 88 (2004) 571-582.

[30] H.Y. Zhang, On the effectiveness of the EPR radical equilibration technique in estimating $\mathrm{O}-\mathrm{H}$ bond dissociation enthalpies of catechols and other complex polyphenols, New J. Chem. 28 (2004) 1284-1285. 
[31] H.Y. Zhang, Y.M. Sun, X.L. Wang, Substituent effects on $\mathrm{O}-\mathrm{H}$ bond dissociation enthalpies and ionization potentials of catechols: A DFT study and its implications in the rational design of phenolic antioxidants and elucidation of structure-activity relationships for flavonoid antioxidants, Chem-Eur. J. 9 (2003) 502-508.

[32] K.I. Priyadarsini, D.K. Maity, G.H. Naik, M.S. Kumar, M.K. Unnikrishnan, J.G. Satav, Role of phenolic O-H and methylene hydrogen on the free radical reactions and antioxidant activity of curcumin, Free Radical Bio. Med. 35 (2003) 475-484.

[33] N. Russo, M. Toscano, N. Uccella, Semiempirical molecular modeling into quercetin reactive site: Structural, conformational, and electronic features, J. Agric. Food Chem. 48 (2000) 3232-3237.

[34] S.J. Wright, R.E. Jonhson, A.G. DiLabio, Predicting the activity of phenolic antioxidants: Theoretical method, analysis of substituent effects, and application to major families of antioxidants, J. Am. Chem. Soc. 123 (2001) 1173-1183.

[35] Y.H. Zhang, M.Y. Sun, Z.D. Chen, O-H bond dissociation energies of phenolic compounds are determined by field/inductive effect or resonance effect? A DFT study and its implication, QSAR 20 (2001) 148-152.

[36] Z.S. Marković, J.M.D. Marković, Ć. Doličanin, A PM6 study on the reactivity of $\mathrm{OH}$ groups in fisetin: Structural and electronic features of fisetins radicals, J. Ser. Soc. Comp. Mech. 3 (2009) 43-55.

[37] P. Mulder, G.H. Korth, U.K. Ingold, Why quantum-thermochemical calculations must be used with caution to indicate a promising lead antioxidant, Helv. Chim. Acta 88 (2005) 370-374.

[38] R.H. Thomson, Natural Occurring Quinones, Academic Press, London, New York, 1971.

[39] Gaussian 09, Revision A.1-SMP, Gaussian Inc., 2009, Wallingford, CT.

[40] A. D. Becke, Density-functional thermochemistry. 2. The effect of the Perdew-Wang generalized-gradient correlation correction, J. Chem. Phys. 97 (1992) 9173$-9177$.

[41] A.D. Becke, Density-functional thermochemistry. 3. The role of exact exchange, J. Chem. Phys. 98 (1993) 5648$-5652$.

[42] C. Lee, W. Yang, R.G Parr, Development of the ColleSalvetti correlation-energy formula into a functional of the electron density, Phys. Rev., B 37 (1988) 785-789.

[43] S. Miertuš, S. Scrocco, J. Tomasi, Electrostatic interaction of a solute with a continuum. A direct utilizaion of $A B$ initio molecular potentials for the prevision of solvent effects, Chem. Phys. 55 (1981) 117-129.

[44] J. Tomasi, B. Mennucci, R. Cammi, Quantum mechanical continuum solvation models, Chem. Rev. 105 (2005) 2999-3094.
[45] N.M. O'boyle, A.L. Tenderholt, K.M. Langner, cclib: A library for package-independent computational chemistry algorithms, J. Comp. Chem. 29 (2008) 839-845.

[46] G.A. Zhurko, D. A. Zhurko, Chemcraft 1.6, Chemcraft graphical program for working with quantum chemistry results, 2009. Available from: http://www.chemcraftprog.com (accessed on Feb, 2013).

[47] R. Ditchfield, Self-consistent perturbation theory of diamagnetism, Mol. Phys. 27 (1974) 789-807.

[48] K. Wolinski, J. Hilton, F.P. Pulay, Efficient implementation of the gauge-independent atomic orbital method for NMR chemical shift calculations, J. Am. Chem. Soc. 112 (1990) 8251-8260.

[49] J.P. Merrick, D. L. Moran, L. Radom, An evaluation of harmonic vibrational frequency scale factors, J. Phys. Chem. 111 (2007) 11683-11700.

[50] J.P. Foster, F. Weinhold, Natural hybrid orbitals, J. Am. Chem. Soc. 102 (1980) 7211-7218.

[51] C.H.G. Derksena, A.G.H. Niederlanderb, A.T. van Beek, Analysis of anthraquinones in Rubia tinctorum L. by liquid chromatography coupled with diode-array UV and mass spectrometric detection, J. Chromatog., A 978 (2002) 119-127.

[52] S.Z. Marković, T.N. Manojlović, DFT study on the reactivity of $\mathrm{OH}$ groups in emodin: structural and electronic features of emodin radicals, Monatsh. Chem. 140 (2009) 1311-1318.

[53] S.Z. Marković, T.N. Manojlović, Analytical characterization of lichexanthone in lichen: HPLC, UV spectroscopic, and DFT analysis of lichexanthone extracted from Laurera benguelensis (Mull. Arg.) Zahlbr, Monatsh. Chem. 141 (2010) 945-952.

[54] S. Møller, K.B. Andersen, J. Spanget-Larsen, J. Waluk, Excited-state intramolecular proton transfer in anthraxlin: Quantum chemical calculations and fluorescence spectra, Chem. Phys. Lett. 291 (1998) 51-56.

[55] S.A.B.E. van Acker, M.J. Groot, W.J.F. van der Vijgh, M.N.J.L. Tromp, G.F. den Kelder, E.J.F. van der Vijgh, A. Bast, A Quantum chemical explanation of the antioxidant activity of flavonoids, Chem. Res. Toxicol. 9 (1996) 1305-1312.

[56] C.A. Rice-Evans, N.J. Miller, G. Paganga, Structure-antioxidant activity relationships of flavonoids and phenolic acids, Free Radic. Biol. Med. 20 (1996) 933-956.

[57] Y.Z. Cai, M. Sun, J. Xing, Q. Luo, H. Corke, Structure-radical scavenging activity relationships of phenolic compounds from traditional Chinese medicinal plants, Life Sciences 78 (2006) 2872-2888.

[58] S.Z. Marković, J.M. Dimitrić-Marković, Ć.B. Doličanin, Mechanistic pathways for the reaction of quercetin with hydroperoxy radical, Theor. Chem. Acc. 127 (2010) 69-80 . 


\section{IZVOD}

\section{HPLC, UV-vis, NMR spektroskopska i DFT karakterizacija purpurina izolovanog iz Rubia tinctorum L.}

Zoran S. Marković ${ }^{1}$, Nedeljko T. Manojlović Svetlana R. Jeremić $^{2}$, Miroslav Živić ${ }^{3}$

${ }^{1}$ Državni univerzitet u Novom Pazaru, Departman za hemijsko-tehnološke nauke, Novi Pazar, Srbija

${ }^{2}$ Univerzitet u Kragujevac, Fakultet medicinskih nauka, Departman za farmaciju, Kragujevac, Srbija

${ }^{3}$ Univerzitet u Beogradu, Biološki fakultet, Beograd, Srbija

(Naučni rad)

Purpurin (1,2,4-trihidroksiantrahinon), prirodni pigment antrahinonske strukture koji se nalazi u korenu biljke Rubia tinctorum, izolovan je iz ove biljke, prečišćen i okarakterisan primenom HPLC hromatografije, UV-vis i NMR spektroskopije. Geometrije konformera purpurina optimizovane su korišćenjem B3LYP/6$311+G(d, p)$ nivoa teorije. Nađeno je da svi konformeri purpurina imaju slične energije, kao i da odgovarajući radikal purpurina ima planarnu strukturu. U svetlu ove planarnosti, zaključeno je da ne postoji značajna delokalizacija elektrona iznad prstenova A i C. Antioksidativne osobine purpurina određene su kolorimetrijski, primenom Troloksa, čiji je oksidativni kapacitet uzet za ekvivalent i teorijski, primenom $B D E$ (eng. Bond Dissociation Enthalpy) metode. Obe ove metode su potvrdile odličan antioksidativni kapacitet purpurina.

Ključne reči: Rubia tinctorum • HPLC-UV

- Antioksidativna aktivnost • DFT studija 